\title{
HUBUNGAN PENGETAHUAN DAN PERILAKU MANDI SANTRI PUTRI TERHADAP KEJADIAN SCABIES DI PONDOK PESANTREN JLAMPRANG KABUPATEN BATANG
}

\author{
Sonhaji, Witri Hastuti, Intan Marliana Safitri \\ STIKes Karya Husada Semarang, Jl. Kompol R. Soekanto No.46 Semarang, (024)6724581 \\ Email: soni_aji84@yahoo.com
}

\begin{abstract}
ABSTRAK
Scabies adalah penyakit menular disebabkan infestasi sarcoptes scabiei varian hominis dan produknya. Data dari Puskesmas Bawang tahun 2016, angka kejadian penyakit scabies sebanyak 300 orang. Data yang paling banyak mengalami penyakit scabies yaitu santri putra putri sebanyak $236(78,6 \%)$ orang dan untuk orang diluar pondok pesantren sebanyak $64(21,4 \%)$ orang. Penelitian ini untuk mengetahui hubungan pengetahuan dan perilaku mandi Santri Putri terhadap Kejadian penyakit scabies di Pondok Pesantren Jlamprang Kecamatan Bawang Kabupaten Batang.Jenis penelitian yang digunakan adalah kuantitatif dengan pendekatan cross sectional.Populasi adalah seluruh santri putri di Pondok Pesantren Jlamprang sebanyak 48 orang. Hasil penelitian ditunjukkan sebagian besar Santri Putri mempunyai pengetahuan kurang baik yaitu 23 responden $(53,5 \%)$, perilaku kurang baik sejumlah 25 responden $(58,1 \%)$ dan kejadian scabies 22 respondne (51,2\%).Ada hubungan antara Pengetahuan dan perilaku santri putri dengan kejadian penyakit scabies.di pondok pesantren Jlamprang Desa Jlamprang Kecamatan Bawang Kabupaten Batang.
\end{abstract}

Kata kunci: pengetahuan; perilaku; kejadian scabies.

\begin{abstract}
Scabies is an infectious disease caused by sarcoptes scabiei infestation and hominis variants. Data from Bawang Health Center in 2016 showed that the number of scabies was 300 people. The data that most experienced scabies were male and female students of 236 (78.6\%) people and for those outside the boarding school as many as 64 (21.4\%) people. This research was to find out the relationship between knowledge and bathing behavior of female Santri to the incidence of scabies in Jlamprang boarding school, Bawang District, Batang Regency. This type of research was quantitative with a cross sectional approach. The population was all 48 female students at Jlamprang boarding school. The results showed that most female students had poor knowledge, namely 23 respondents (53.5\%), unfavorable behavior of 25 respondents (58.1\%) and the incidence of 22 respondent scabies (51.2\%). There is a relationship between knowledge and behavior of female students with the incidence of scabies. In the boarding school Jlamprang, Jlamprang Village, Bawang District, Batang Regency.
\end{abstract}

Keywords: behavior; knowledge; the incidence of scabies 


\section{LATAR BELAKANG}

Scabies adalah penyakit menular disebabkan infestasi Sarcoptes Scabiei varian hominis dan produknya (Wawan, 2010) . Scabies disebut juga the itch, Norwegian itch, gudikan, gatal agogo, budukan atau penyakit amper (Atikah, 2012). Penyebab penyakit scabies sudah dikenal lebih dari 100 tahun lalu sebagai akibat infestasi tungau yang dinamakan Acarus Scabiei atau pada manusia disebut Sarcoptes Scabiei varian hominis. Sarcoptes Scabiei termasuk dalam Arthropoda, kelas Arachnida (Djuanda, 2011). Oleh karena itu, prevalensi scabies yang tinggi umumnya ditemukan di lingkungan dengan kepadatan penghuni dan kontak interpersonal tinggi seperti penjara, panti asuhan, dan pondok pesantren (Harahap, 2011).

Sebanyak 300 juta orang pertahun di dunia dilaporkan terserang scabies (WHO, 2017). Selain itu scabies juga ditemukan pada semua negara dengan prevalensi yang bervariasi. Prevalensi scabies di Indonesia menurut Depkes RI berdasarkan data puskesmas seluruh Indonesia tahun 2016 adalah 7,4\% - 12,9. Di Bantul tahun 2015 prevalensi scabies yaitu $7,5 \%$ dan di Semarang mencapai 5,8\%.

Berdasarkan data yang terdapat di Dinas Kesehatan Provinsi Jawa Tengah tahun 2016, kejadian scabies di 20 puskesmas menunjukkan bahwa kejadian terbanyak terdapat di daerah Cilacap dengan jumlah $46,8 \%$ kasus, urutan kedua terbanyak adalah di daerah Bukateja dengan jumlah 34,2\% kasus dan urutan ketiga terbanyak terdapat di daerah Semarang dengan jumlah 19\% kasus( Dinkes, 2018).

Menurut Dinas Kesehatan Kabupaten Batang tahun 2016 kejadian scabies berjumlah
1195 kasus baru dan 328 kasus lama. Data Puskesmas Bawang pada tahun 2016 angka kejadian penyakit scabies sebanyak 300 orang. Data yang paling banyak mengalami penyakit scabies yaitu santri putra putri sebanyak 236 $(78,6 \%)$ orang dan untuk orang diluar pondok pesantren sebanyak $64(21,4 \%)$ orang.

Berdasarkan studi pendahuluan di Pondok Pesantren Jlamprang jumlah santri 183 orang, santri laki-laki sebanyak 100 orang dan santri perempuan sebanyak 83 orang. Santri putri yang berusia 22 tahun berjumlah 1 orang, berusia 21 tahun berjumlah 3 orang, santri putri berusia 20 tahun berjumlah 8 orang , santri putri berusia 19 tahun berjumlah 7 orang, santri putri berusia 18 tahun berjumlah 13 orang, santri putri yang berusia 17 tahun berjumlah 15 orang, santri putri berusia 16 tahun berjumlah 16 orang, santri putri yang berusia 15 tahun berjumlah 7 orang, santri putri yang berusia 14 tahun berjumlah 5 orang, santri putri berusia 13 tahun berjumlah 3 orang, santri putri yang berusia 12 tahun 2 orang.Berdasarkan latar belakang tersebut, penelitian dilakukan untuk mengetahuihubungan pengetahuan dan perilaku mandi Santri Putri terhadap kejadian scabies di Pondok Pesantren Jlamprang.

\section{METODE}

Jenis penelitian ini adalah kuantitatif, dengan desain deskriptif correlation ( Notoatmodjo, 2012). Metode pendekatan yang digunakan adalah cross sectional. Populasi penelitian ini sebanyak 48 Santri Putri di Pondok Pesantren Jlamprang Kecamatan Bawang. Teknik pengambilan sampel menggunakan teknik purposive sampling. Analisa data menggunakan uji Chi Square (Notoatmodjo, 2012) .

\section{HASIL}

Hubungan antara pengetahuan Santri Putri dengan kejadian scabies di Pondok Pesantren Jlamprang Kecamatan Bawang Kabupaten Batang.

\begin{tabular}{|c|c|c|c|c|c|c|c|}
\hline \multirow{3}{*}{ Pengetahuan } & \multicolumn{4}{|c|}{ Kejadian scabies } & \multirow{2}{*}{\multicolumn{2}{|c|}{ Jumlah }} & \multirow{3}{*}{$\begin{array}{c}P \\
\text { value }\end{array}$} \\
\hline & \multicolumn{2}{|c|}{ Scabies } & \multicolumn{2}{|c|}{$\begin{array}{c}\text { Tidak } \\
\text { scabies }\end{array}$} & & & \\
\hline & $\mathrm{F}$ & $\%$ & $\mathrm{~F}$ & $\%$ & $\mathrm{~F}$ & $\%$ & \\
\hline Baik & 2 & 10,0 & 18 & 90,0 & 20 & 100 & 0,000 \\
\hline Kurangbaik & 20 & 87,0 & 3 & 13,0 & 23 & 100 & \\
\hline Jumlah & 22 & 51,2 & 21 & 48,8 & 43 & 100 & \\
\hline
\end{tabular}


Berdasarkan tabel di atas diketahui bahwa Santri Putri di Pondok Pesantren Jlamprang mempunyai pengetahuan baik dan tidak mengalami kejadian scabies sebanyak 18 responden $(90,0 \%)$ dan mempunyai pengetahuan kurang dengan kejadian scabies sebanyak 20 responden $(87,0 \%)$, dengan $p$ value 0,000 .

\section{Hubungan antara perilaku mandi santri putri dengan kejadian penyakit scabies di Pondok Pesantren Jlamprang Desa Jlamprang Kecamatan Bawang Kabupaten Batang.}

\begin{tabular}{|c|c|c|c|c|c|c|c|}
\hline \multirow{3}{*}{ Perilaku } & \multicolumn{4}{|c|}{ Kejadian scabies } & \multirow{2}{*}{\multicolumn{2}{|c|}{ Jumlah }} & \multirow{3}{*}{$\begin{array}{c}P \\
\text { value }\end{array}$} \\
\hline & \multicolumn{2}{|c|}{ Scabies } & \multicolumn{2}{|c|}{$\begin{array}{l}\text { Tidak } \\
\text { scabies }\end{array}$} & & & \\
\hline & $\mathrm{F}$ & $\%$ & $\mathrm{~F}$ & $\%$ & $\mathrm{~F}$ & $\%$ & \\
\hline Baik & 1 & 5,6 & 17 & 94,4 & 18 & 100 & 0,000 \\
\hline Kurangbaik & 21 & 84,0 & 4 & 16,0 & 25 & 100 & \\
\hline Jumlah & 22 & 51,2 & 21 & 48,8 & 43 & 100 & \\
\hline
\end{tabular}

Berdasarkan tabel di atas diketahui Santri Putri di Pondok Pesantren Jlamprang mempunyai perilaku baik dan tidak ada kejadianscabies sebanyak 17 responden (94,4\%). Responden dengan perilaku kurang baik dan dengan kejadian scabies sebanyak 21 responden $(84,0 \%)$. P value 0,000 yang menyatakan ada hubungan antara perilaku mandi Santri Putri dengan kejadian penyakit scabies di Pondok Pesantren Jlamprang Kecamatan Bawang Kabupaten Batang.

\section{PEMBAHASAN}

Berdasarkan tabel silang di atas maka dapat diketahui bahwa santri putri di pondok pesantren Jlamprang Kecamatan Bawang yang mempunyai pengetahuan baik sebagian besar mempunyai kejadian scabies tidak scabies sebanyak 18 responden $(90,0 \%)$ dan yang mempunyai pengetahuan kurang sebagian besar mempunyai kejadian scabies sebanyak 20 responden $(87,0 \%)$. Berdasarkan hasil olah datadidapatkan nilai $p$ value sebesar $0,000<0,05$, maka ada Hubungan antara Pengetahuan santri putri dengan kejadian penyakit scabies di pondok pesantren Jlamprang Desa Jlamprang Kecamatan Bawang Kabupaten Batang.

Pengetahuan yang kurang tentang penyakit scabies pada santri salah satunya dipengaruhi oleh faktor umur santri masih tergolong pada kategori remaja, sehingga pengetahuan tentang penyakit scabies masih kurang, pengetahuan tentang skabies sangat mempengaruhi kejadian scabies karena pengetahuan merupakan sumber yang sangat penting untuk terbentuknya suatu tindakan seseorang (Ratnasari 2014). Santri kurang memahami tentang cara pencegahan, sumber penularan dan penyebab scabies sehingga penyakit scabies dapat menyerangsantri (Maharani, 2015).

Hal ini sesuai dengan penelitian sebelumnya oleh Akmal (2013) yang menyebutkan terdapat hubungan antara pengetahuan santri dengan perilaku pencegahan penyakit skabies di pondok pesantren dengan nilai $p$ value $=0,001$. Hasil penelitian ini dapat dijelaskan tingkat pengetahuan yang baik, belum tentu pasti terwujud dalam suatu tindakan yang nyata. Dalam mewujudkan pengetahuan menjadi perilaku nyata, dipengaruhi faktor lain seperti faktor pendukung yaitu diantaranya ketersediaan sarana, fasilitas dan kemampuan untuk memenuhi segala kebutuhan dalam perilaku pencegahan, selain itu dibutuhkan juga adanya dukungan dari orang sekitar atau orang terdekat ( Adriani, 2015)

Berdasarkan tabel silang di atas maka dapat diketahui bahwa santri putri di pondok pesantren Jlamprang Kecamatan Bawang yang mempunyai perilaku baik sebagian besar mempunyai kejadian scabies tidak scabies sebanyak 17 responden $(94,4 \%$ ) dan yang mempunyai perilaku kurang baik sebagian besar mempunyai kejadian scabies sebanyak 21 responden $(84,0 \%)$. Berdasarkan hasil olah data didapatkan nilai $p$ value sebesar $0,000<0,05$, 
maka ada Hubungan antara perilaku mandi santri putri dengan kejadian penyakit scabies di pondok pesantren Jlamprang Desa Jlamprang Kecamatan Bawang Kabupaten Batang.

Hal ini disebabkan oleh pengetahuan santri yang kurang tentang penyakit scabies sehingga mempengaruhi perilakusantri tentang kejadian scabies. (Himan, 2016). Santri cenderung acuh dan kurang peduli tentang kesehatan diri dan lingkungan terutama di asrama mereka selalu menggunakan selimut secara bersamaan, menggunakan handuk secara bersamaan dan menggunakan alatsholat secara bersamaan dan tidur secara bersamaan, padahal perilaku tersebut tidak boleh dilakukan karena akan menimbulkan masalah kesehatan terutama terjadinya penyakit kulit sepertipenyakit scabies (susanto, 2013)

Hasil penlitian ini sejalan dengan penelitian sebelumnya oleh Ismail, (2016) yang menyimpulkan ada hubungan hygiene perorangan, sanitasi lingkungan dan riwayat kontak dengan penyakit scabies.

\section{KESIMPULAN DAN SARAN}

Santri putri di Pondok Pesantren Jlamprang Kecamatan Bawang mempunyai pengetahuan kurang baik 23 responden $(53,5 \%)$, perilaku kurang baik 25 responden (58,1\%)dankejadian scabies 22 responden $(51,2 \%)$. Ada hubungan antara pengetahuan santri putri dengan kejadian scabiesdan ada hubungan antara perilaku mandi santri putri dengan kejadian scabies di Pondok Pesantren Jlamprang Desa Jlamprang Kecamatan Bawang Kabupaten Batang. Adanya informasi dan tambahan pengetahuan tentang scabies dan perilaku personal hygiene dapat menjaga kebesihan diri seperti mandi atau membersihkan diri sedikitnya 2 kali sehari dengan menggunakan sabun mandi untuk menghilangkan kotoran dan kuman di badan.

\section{REFERENSI}

Adriani (2015). Hubungan Pengetahuan Santri dengan Kejadian Penyakit Skabies di pondok pesantren Al Muayyad Surakarta.J. Kesehat. Masy. Indones.Vol. 3 No.1 April 2015.
Akmal, SC, Rima Semiarty, Gayatri 2013, 'Hubungan personal hygiene dengan kejadian skabies di pondok pendidikan islam darululum, palarik air pacah, kecamatan kototangah padang tahun 2013', Jurnal Kesehatan Andalas, vol.2, no.3, 2013, hlm. 165-166.

Atikah D, (2012), Perilaku Hidup Bersih Dan Sehat (PHBS), Nuha Medika,Yogyakarta)

Djuanda A, (2011), IImu penyakit kulit dan kelamin, Jakarta: Fakultas Kedokteran Universitas Indonesia ed.5.

Harahap, (2011), IImu Penyakit Kulit, Jakarta: Hipokrates

Hilma, UD \& Ghazali L 2016, 'Faktor-faktor yang mempengaruhi kejadian skabies di pondok pesantren mlangi nogotirto gamping sleman yogyakarta', JKKI, vol.6, no.3, Juni- Agustus 2017, hlm. 150

Maharani. 2015. Penyakit kulit, perawatan, pencegahan dan pengobatan. Yogyakarta. Pustaka Baru Press.

Notoatmodjo.Soekidjo.2012. Promosi Kesehatan teori dan Aplikasi.Jakarta : Rineka Cipta

Sa'adatin, Mu'linatu \& Toto Suyoto, Ismail 2016 ' Hubungan Higiene perorangan, sanitasi lingkungan dan Riwayat Kontak dengan Kejadian Skabies ' J. Kesehat. Masy. Indones. 10 (1) 2015

Pemerintah Kabupaten Batang.Dinas Kesehatan.; 2018

Ratnasari, AF \&Saleha, S 2014, 'Prevalensi Skabies dan Faktor-faktor yang Berhubungan di Pesantren X, Jakarta Timur', eJKI, vol.2 no.1, April 2014, hlm. 2, 254.

Susanto.R Clevere.2013. Penyakit Kulit dan Kelamin.Yogyakarta :Nuha medika.

Wawan.A . 2010. Teori dan pengukuran Pengetahuan, sikap, dan perilaku manusia. Yogyakarta.Nuha medika.

WHO. 2017. Skabies. Online http;//www.who.int/neglected_diseases/disea s es/scabies/en/aboutscabies/. 